\title{
衝撃砕波力の数值解析
}

\section{NUMERICAL SIMULATION OF THE IMPACT BREAKING WAVE FORCE ACTING ON THE BREAKWATER}

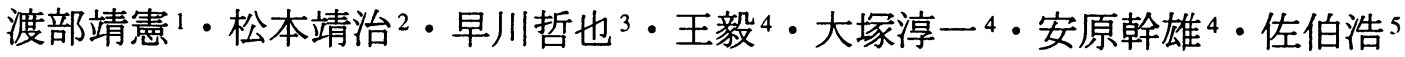 \\ Yasunori WATANABE, Yasuharu MATSUMOTO, Tetsuya HAYAKAWA, Yi WANG, Jun-ichi \\ OHTSUKA, Mikio YASUHARA and Hiroshi SAEKI

\begin{abstract}
1 正会員 工博 北海道大学助手 工学研究科環境資源工学専攻（ $\bar{T} 060-8628$ 札幌市北区北 13 条西 8 丁目） 2 正会員 東亜建設（株）横浜営業所（广 231-0011 横浜市中央区太田長町 1 丁目 15 番地） 3 正会員 北海道開発局開発土木研究所 港湾研究室 ( $\bar{T} 062$ 札幌市豊平区平岸 1 条 3 丁目) 4 学生員 工学研究科環境資源工学専攻 ( $\mathrm{T}$ 060-8628 札幌市北区北 13 条西 8 丁目)
\end{abstract} \\ 5 正会員 工博 北海道大学教授 工学研究科噮境資源工学専攻（ $\mathrm{T} 060-8628$ 札幌市北区北 13 条西 8 丁目）
}

\begin{abstract}
When the overturning jet of broken wave hits a wall of coastal structure such as a breakwater, the impact force acts on the structure, which often give a great damage to the structure. Although there have been many reports on the impact force, little is known about the quantitative properties of the force and velocity fluctuation in time. In this paper, the plunging jet attacking to the structure was numerically solved by the direct numerical scheme with the high level of accuracy. The correlations between the surface profiles, the direction of fluid velocity and the pressure were also discussed through the investigations of spatial and temporal changes of them.
\end{abstract}

Key Words: Overturning jet, impact wave pressure, numerical simulation

1.はじめに

急勾配地形を有する浅海域に防波堤を設置する場 合や大波浪時には非線形性の強いあるいは砕波を 伴う波浪が堤体に衝突する。この時堤体にはたら く最大波圧は通常のものと比べて大きく, 最大波 圧が発生する時間間隔は非常に短い。こうした衝 撃矿波力は海岸構造物・消波工の安定及び破壊の 重要な原因の一つと考えられるが，その力学特性 は未だ十分に解明されているとはいえない。

防波堤にはたらく波圧は従来合田式により与えら れてきたが, 堤体前面海底勾配を有する場合, この 衝撃砕波の発生のため合田式によるものと大きく 異なる力が働くことは以前から指摘されてきた (例えば, P. Klammer et $\mathrm{al}^{2}$ ). 一方, 数值解析は流 体運動について詳細な時空間データを供給するこ とができるが, この問題の様に急速に力学的変化 をもつ問題は数值不安定が誘発され計算の実行が 不可能となる可能性が高く, 現在まで多くの成功 例が得られているとはいえない。
著者らは巻き波砕波の数值シミュレーションゔ通 してその計算手法の妥当性を検証してきた. 本研究は鉛直壁に作用する衝撃砕波庄特性を解明 する基礎的研究として同様な計算手法を用いてこ の問題に適用し，鉛直壁に衝突する波の位相を変 化させ, 流速及び圧力場を解析しそれらの力学機 構を議論するものである.

\section{2. 計算方法}

著者らの過去の計算法 ${ }^{5)}$ と同様にCrank-Nicholson 法, CIP法を結びつけ, Navier-Stokes式を直接計算 し,この現象を再現する.この計算において, 水面 は密度関数法により検出され，底面及び防波堤堤 体にはノンスリップ条件が与えられている．入射 波として造波境界において，2次のクノイド波が 与えられた。

簡単に衝撃砕波を再現するためにAzarma et al.。”の 模型実験と同様に図1に示すようなステップをもち 鉛直壁を終端にもつ計算領域を採用した。ステッ 
プから構造物までの距離 Ls を変化させ衝突状態の 異なる砕波ジェットによる衝撃砕波力を調べた。 結果で示す值は全て造波境界前面の水深 $\mathrm{h}_{0}$, 波速 $\mathrm{C}$, 水の密度 $\rho_{\mathrm{w}}$ で無次元化されている. 波浪条件は, $\mathrm{H} / \mathrm{h}=0.55, \mathrm{~m}=0.95, \mathrm{Re}=181865(\mathrm{H}$ : 波高, $\mathrm{h}:$ 水深 , $\mathrm{m}$ : 楕円関数の母数, $\mathrm{Re}:$ Reynolds 数)である. ま た，タイムステップ $\mathrm{dt}=\mathrm{T} / 1024$, グリッド間隔 $\mathrm{dx}=0.03$ とした。この波浪条件は実験室規模で波高 $20 \mathrm{~cm}$, 周期 $1.7 \mathrm{sec}$, 水深 $45 \mathrm{~cm}, \mathrm{~B}=50 \mathrm{~cm}$ に対応す る.また, ステップ高； $0.6 \mathrm{y} / \mathrm{h}_{0}$, ステップ前面から 造波境界までの距離； $14 \mathrm{x} / \mathrm{h}_{0}$ であり，ステップ前面 から堤体までの距離 Ls=2.0（砕波直前）, 3.1（挽波 点）, 4.0,6.0についてそれぞれ計算を行った. この問題に対して混入される気泡及び空気塊の影 響を指摘する多くの報告があるが（例えば, Hattori et al. ${ }^{1,4)}$ ), 本計算では直接砕波力として構造物に影 響を与える流体運動が依然支配的であるとして， これらの影響は無視した。この計算結果は, 気泡か らの寄与がない流体のみのモデルを適用した現象 と位置づけられ，第一近似として衝撃砕波力の定 性的傾向を把握することができる.

\section{3. 結果}

\section{(1)砕波直前に堤体に衝突するケース}

図 2 は, Ls=2.0 (砕波直前)に堤体を設置したケー スの波のフロントが堤体に衝突する前後の特徵的 な位相の流速ベクトル図を示したものである.(a)に 示される波のフロントが堤体に衝突する直前の位 相において，波のフロント近傍で水平流速が卓越 するが，衝突後，急速に鈆直上向きに方向を変え大 きな加速度をもって重複波が形成されていく過程 がわかる.この様に, 衝撃的流体運動をもつこの現 象も，本計算手法により安定して計算を行うこと ができた。

図 3 は, 壁面にはたらく全圧の時系列を示してい る.図 2 における位相 $(a) \sim(c)$ は図中のそれぞれの 矢印の位相を表している.フロント衝突後, 急激に 圧力が上昇し, その後減衰しながら位相(c)で小さ な極大值をもつ、時間の経過と共に圧力は極小值 (d)をとり, その後再び緩やかな極大值(e)をもつ. この結果は波圧に関する過去の多くの実験結果と 定性的に対応し, 衝撃砕波力が発生する全圧の実 験結果(P. Klammer et $\left.\mathrm{a}^{2}{ }^{2}\right)$ とも同じ傾向をもつ. 図 4 は, この時の堤体前面の水位変動の時系列を 表している. 水位は密度関数（流体内で 1 , 流体外 で0の值をもつ）の鉛直積分值と定義され， $\mathrm{x}$ 軸に

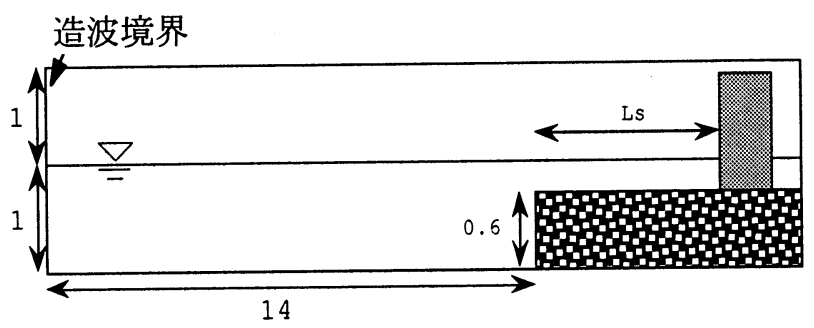

図 1 計算領域（次元は $\mathrm{h}_{0}$ による無次元量）

(a)

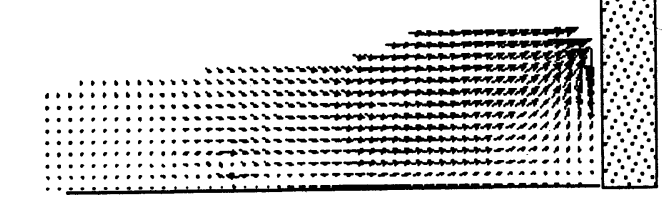

(b)

(c)

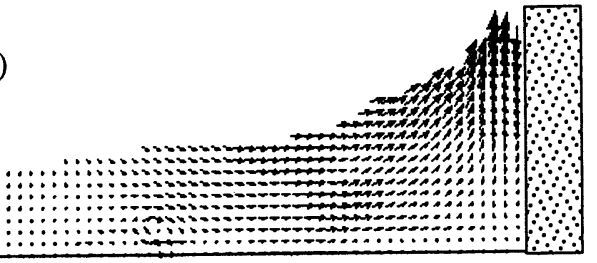

図 2 衝撃波圧発生前後の流速ベクトル (位相間隔；20t/T, Ls=2.0)

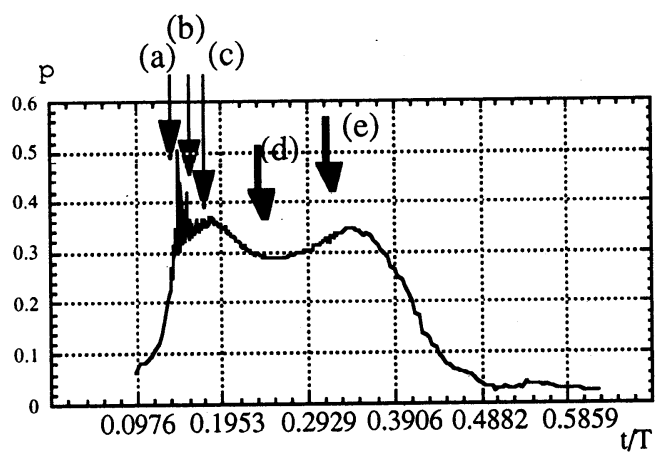

図 3 堤体前面にはたらく全圧変化 $(L s=2.0)$

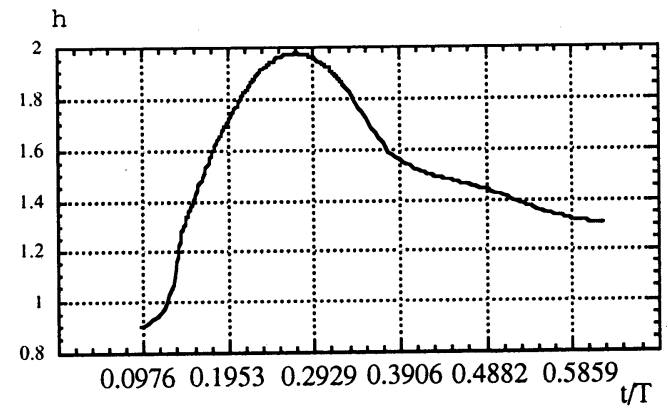

図 4 堤体前面における水位変動 $(\mathrm{Ls}=2.0)$ 
関して 2 価となる様なジェットの巻き込みは表現 されない.フロントの衝突前から急速に水位が上 昇し, 衝突後その勾配は若干緩やかになり約 $0.1318 \mathrm{t} / \mathrm{T}$ 後に最大值をもつ. 一方, 図 3 と図 4 を 比較すると，両者が定性的に対応しない.ある程度 の規模以上の大きな運動量をもつ波浪が重複波と なるとき，大きな鉛直流速が発生するためすでに 圧力が水位変動による静水圧で近似できず水位変 動と圧力変動にタイムラグがうまれることを示し

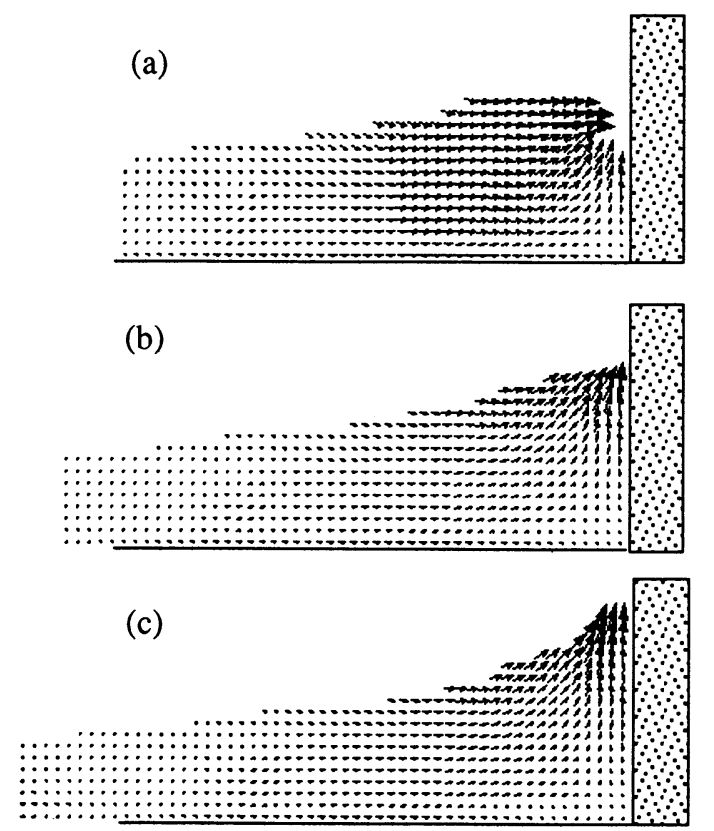

図 5 衝撃波圧発生前後の流速べクトル (位相間隔 ; 20t/T, Ls=3.1)

(a)

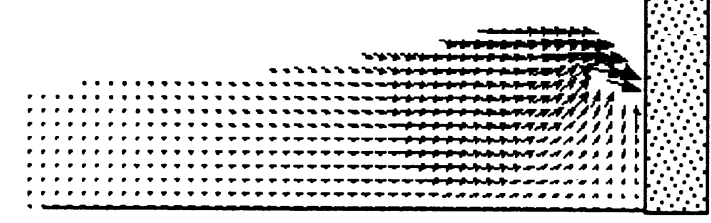

(b)

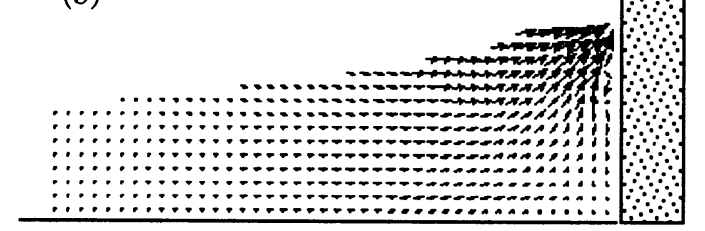

(c)

図 8 衝撃波圧発生前後の流速ベクトル (位相間隔 ; 20t/T, Ls=4.0)
ている。衝撃砕波圧が発生する位相では水平方向 の運動量が壁面で 0 になるための圧力ピークが表 れ，水位上昇による重複波圧は第 2 極大值に表れ る (図 3 (e)参照)。水位が静水位以上となる位相と 最大砕波圧発生の位相差を $\mathrm{t}_{0}$, 最大衝撃砕波圧発生 の位相と水位変動のピークまでの位相差を $\mathrm{t}_{1}$, 水位 上昇のピークとこの圧力の第 2 ピークの位相差を $\mathrm{t}_{2}$ とすれば, 基本周期との無次元量で $\mathrm{t}_{0}=0.0146$, $\mathrm{t}_{1}=0.1318, \mathrm{t}_{2}=0.0635$ であった.

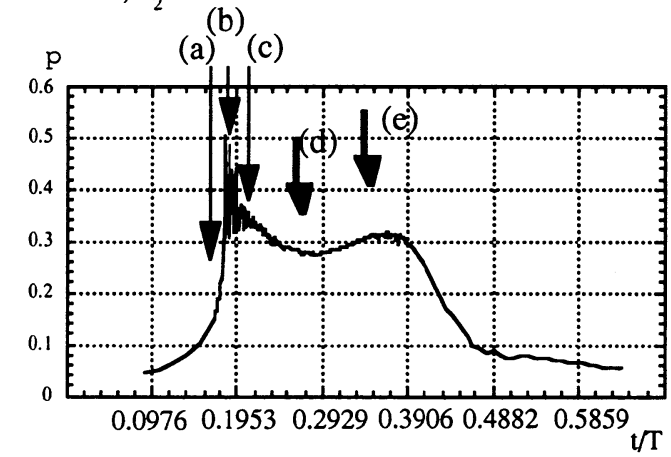

図 6 堤体前面にはたらく全圧変化 $(L s=3.1)$

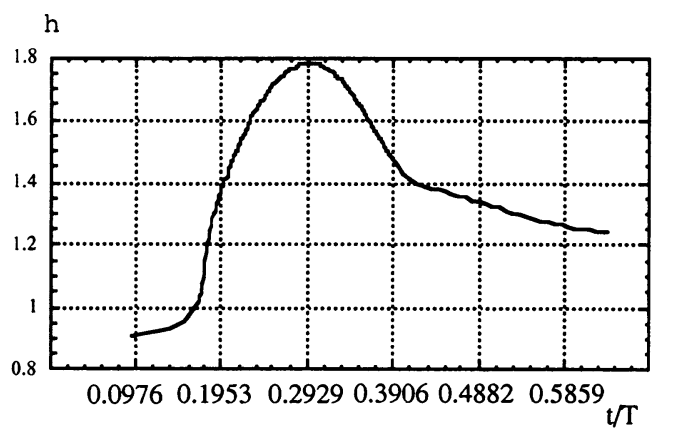

図 7 堤体前面における水位変動 $(\mathrm{Ls}=3.1)$ (a) (b)

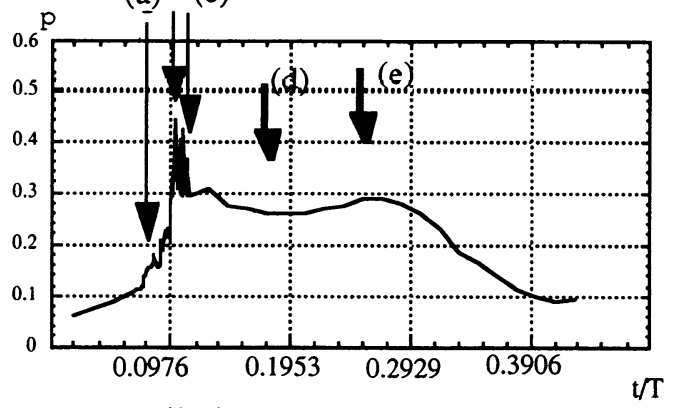

図 9 堤体前面にはたらく全圧変化 $(\mathrm{L} s=4.0)$

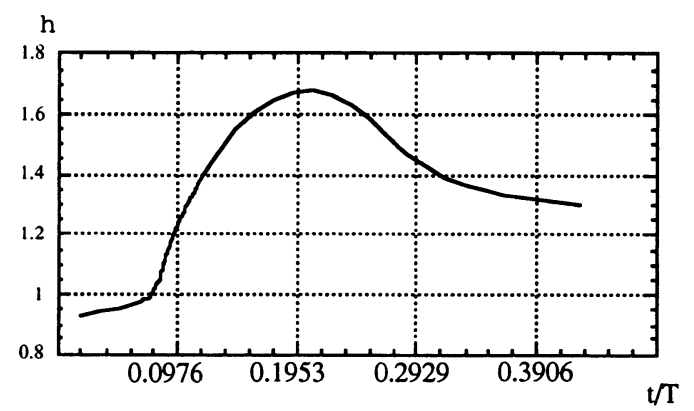

図 10 堤体前面における水位変動 $(\mathrm{Ls}=4.0)$ 
（2）砕波点に堤体があるケース

図 5 は，ほぼ砕波点に堤体を設置した場合の流速 ベクトルの特徵的な 3 つの位相における流速べク トルを表している．水平流速の卓越する巻き込み ジェットが堤体に衝突し, 前ケースと同様に強い 鉛直流速が発生し波が打ち上げられるのがわかる. この時の堤体にはたらく全圧及び堤体前面の水位 変動の時系列がそれぞれ図 6 , 図 7 に示されてい る.(1)のケースと比べて衝撃砕波圧発生直前の波圧 の時間変化は大きいが, 最大波圧はほぼ同程度で あり，前述した極小值及び第 2 極大值の絶対值及 び変動共にやや低い值となった，衝撃砕波発生前 の水位変動の時間変化もこのケースの方が大きく なる.また, $\mathrm{t}_{0}=0.0176, \mathrm{t}_{1}=0.1142, \mathrm{t}_{2}=0.0732$ であっ た.

\section{（3）砕波直後に堤体に衝突するケース}

図 8 は, 砕波直後の巻き込みジェットが斜め前方 に落下しながら堤体に衝突する場合の典型的な位 相の流速べクトルを表したものである. (a)の位相で ジェットがほぼ着水点付近で堤体に衝突する. (1), (2)のケースと異なり．その後堤体の極近傍で大き な鉛直流速は発生せず沖側のトラフレベル以上の 領域で斜め上方の流速の方が顕著に表れ，(c)におい て鉛直上向き流速は前ケースと比べ小さいことが わかる. 水位変動のピークが堤体に到達する位相

(a)

(b)

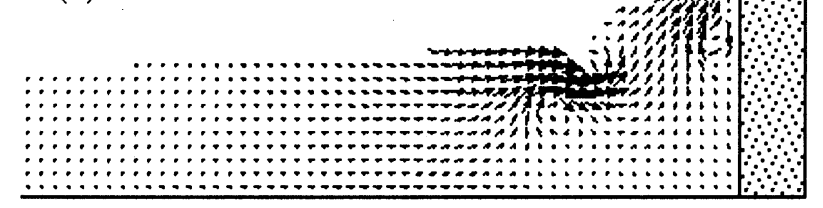

(c)

図 11 衝撃波圧発生前後の流速ベクトル (位相間隔 ; 20t/T, Ls=6.0)
とジェット先端が衝突する位相との間隔大きくな り，重複波形成過程が変わることが原因といえる。 図 9, 図 10 は, このケースにおける全圧と水位変 動の同様な図である. ジェットが到達する(a)の位 相で全圧に小さな変動がみられ, (b)の水位のピーク の位相が堤体に到達する時, 最大砕波圧が発生す る. 衝突後の鉛直流速が前ケースと比べ小さいの で衝撃砕波圧発生後の(d), (e)を含めた圧力の変動, 絶対值共に小さくなる. 波の打ち上げ高さは前 ケースと比べ 2 割ほど低下し, 水位変動の時間変 化もかなり小さくなる. また, $\mathrm{t}_{0}=0.0225, \mathrm{t}_{1}=0.1094$, $\mathrm{t}_{2}=0.0537$ であった.

\section{（4）着水点背後に堤体を設田したケース}

図 11 は砕波後ジェットが着水しスプラッシュアッ プしたジェットが堤体に衝突する場合の典型的な 3 つの位相に対する流速べクトルを表している. 堤体に衝突する流体は水平流速の卓越したジェッ 卜部が殆どであり，堤体前面の領域に流入する運 動量は着水に伴う散逸の影響もあり大きくないた め, 流体の鉛直方向への打ち上げも大きくない。こ のケースにおける堤体にはたらく全圧及び堤体前 面の水位変動が図12，13 に表されている．特に衝 撃的な波圧の上昇は極端に小くなり，全体的に前 ケースと比較して変動, 絶対值共に小さくなる. 水 位変動量も同様に小さくなり, 最大打ち上げ高さ は(1)のケースと比べ約 $1 / 2$ 程度となる。また，

(b)

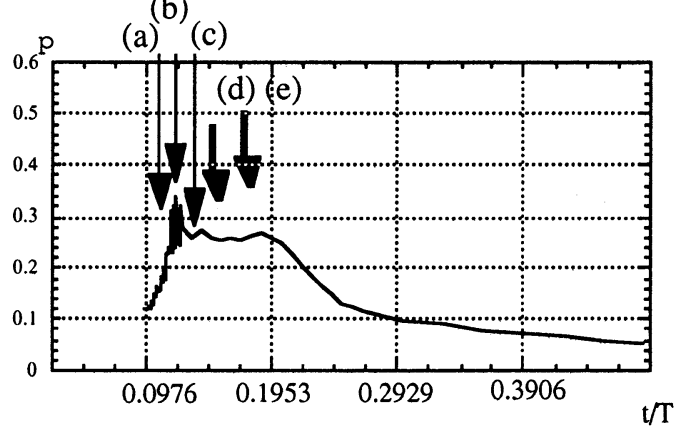

図 12 堤体前面にはたらく全圧変化 $(\mathrm{Ls}=6.0)$

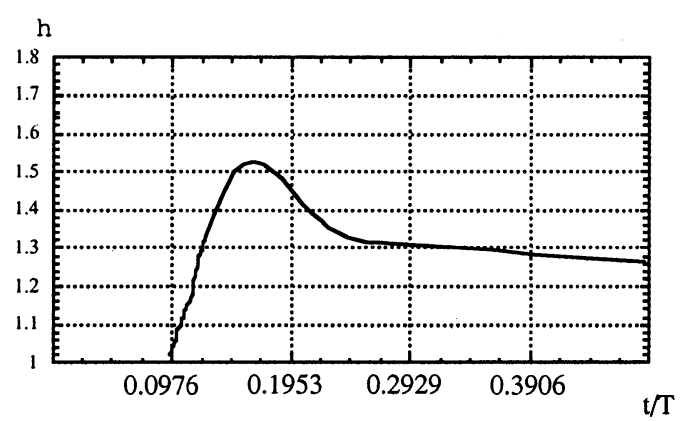

図 13 堤体前面における水位変動 $(\mathrm{Ls}=6.0)$ 
$\mathrm{t}_{0}=0.0322, \mathrm{t}_{1}=0.0459, \mathrm{t}_{2}=0.0244$ であった。

\section{（5）衡撃砕波圧発生時の動压变功について}

図14はLs=3.1におけるジェットが堤体に衝突する 位相(a), 最大衝撃砕波圧が発生する位相(b), 振動 動圧の低下する位相(c)及び水位変動のピークをも つ位相(d)に対する動圧の鉛直分布を表したもので ある.(a)において, $\mathrm{z}=1.2$ 近傍でジェットの衝突に 起因する小さなピークが現れる。このピークが発 達し, (b)の位相では約 $\mathrm{z}=1.27$ の位置で非常に大き な鉛直勾配を持つピークが現れ静水位 $\mathrm{z}=1$ 以上の 領域でも大きな動圧が維持されていることがわか る.この砕波圧の鉛直分布は定性的に Klammer et al. (1996), Azatama et al.(1996)の実験結果と同様 であった.(c)の位相では(b)のようなジェット近傍の 発達したピークは存在しない. (d)の位相における動 圧の鉛直分布から次のように衝撃砕波発生後の圧 力変化の特徵を示すことがでさる. $\mathrm{z}=1$ 以上の領域 の動圧の鉛直勾配は，静水圧分布より鉛直勾配が 小さく，流体の自重がフルに圧力としてはたらい ていないことから，波の衝突に伴う急激な鉛直流 速の発生により流体が鉛直上向きに加速度をもっ て持ち上げられるため圧力が静水圧近似より小さ い值を示し, その後, 重力により下向き加速度が卓 越しだすと十分に圧力としてはたらくため第 2 の 極大值が位相差をもって発生する。

\section{（6）衛敦波問題への数值解析の適用に関する考}

\section{察}

計算で得られた衝撃砕波圧発生直後, 振動を有す
る結果が得られた．数値計算によるこの様な振動 は有限の大きさをもつ時間メッシュによる高周波 変動のカットオフが起因するエイリアシングが発 生している可能性がある。本計算では 1 周期を 1024 ～ 16384 分割までタイムステップ間隔をそれ ぞれ変化させ比較したが同一の周波数でこの振動 が発生し単なるエイリアシングと考えにくい，衝 撃砕波後の減衰振動に関してはHattori et al. (1994) の実験的研究等多くの研究があるが，これらの研 究を踏まえ, 本研究で得られた結果が計算スキー ムの特性に起因する問題なのかあるいは別の問題 なのか今後の計算法の発展のために調べる必要が ある。

\section{4. 結論}

•数值計算により直立壁に衝突する砕波ジェットを 伴う波動卜の流体連動を再現し, 現象解明の第 1 段階として, 壁面の衝突する位相を変化させ, 衝撃 砕波圧を伴う圧力変動と流体運動の変化を調べた。 ・堤体前で水位が上昇開始する位相, 最大衝撃砕波 圧が発生する位相, 最大打ち上げ高さをもつ位相, 再び圧力がピークをもつ第 2 極大值にはそれぞれ 以下のようなタイムラグが発生する（値は入射波 基本周期で無次元化されている).

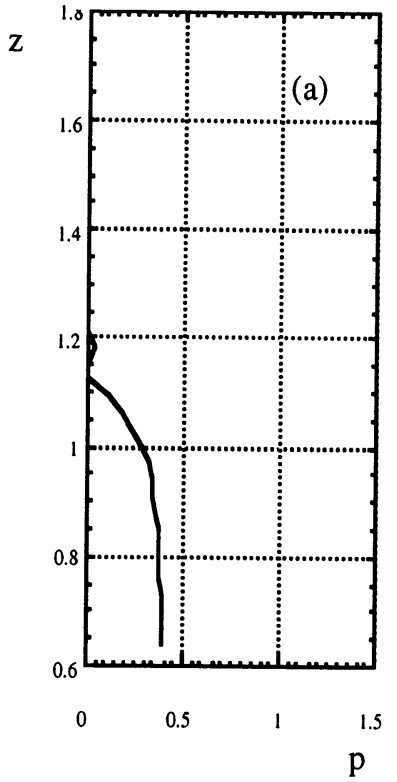

図 14
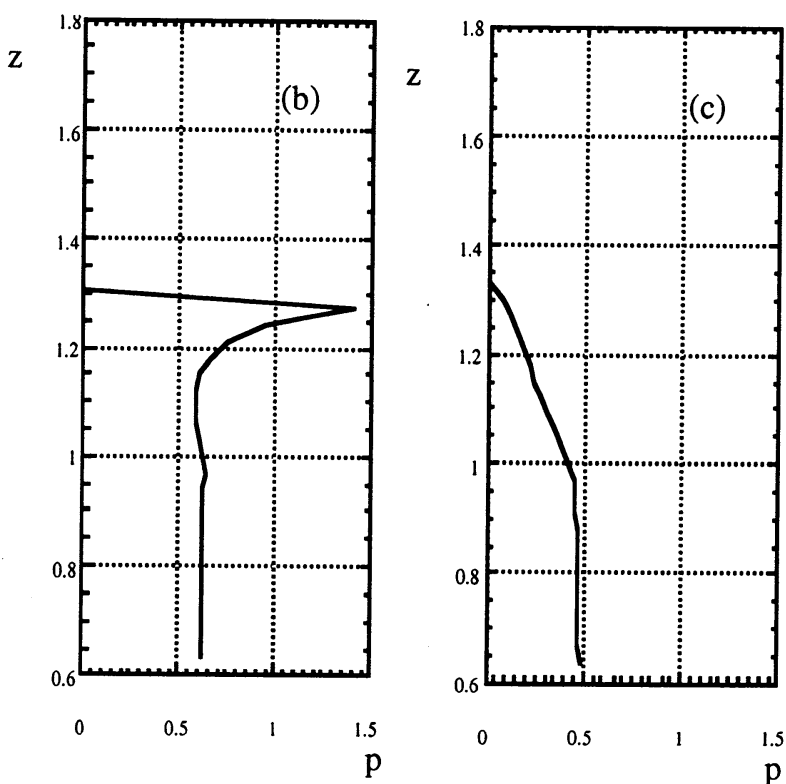

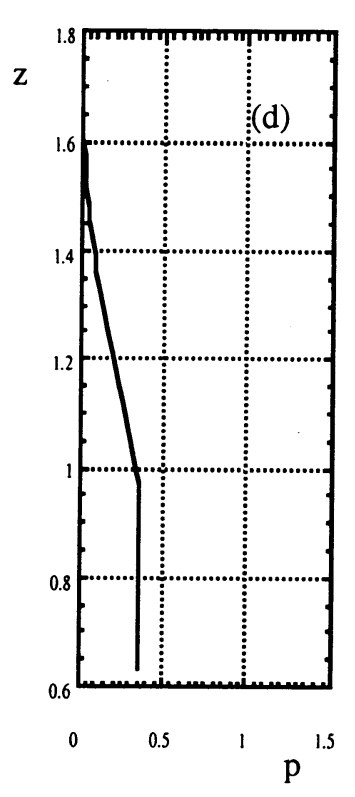




\begin{tabular}{|c|c|c|c|}
\hline Ls & $\mathrm{t}_{0}$ & $\mathrm{t}_{1}$ & $\mathrm{t}_{2}$ \\
\hline 2.0 & 0.0146 & 0.1318 & 0.0635 \\
\hline 3.1 & 0.0176 & 0.1142 & 0.0732 \\
\hline 4.0 & 0.0225 & 0.1094 & 0.0537 \\
\hline 6.0 & 0.0322 & 0.0459 & 0.0244 \\
\hline
\end{tabular}

この波浪条件においては, 砕波過程が進行した位 相において堤体に衝突するほど，水位上昇開始か ら最大砕波圧発生までの時間が長くなり, 最大砕 波圧発生から水位ピークまでの時間及び水位ピー クから第 2 ピーク発生までの時閒は共に短くなる. ・本基礎研究を踏まえ, ジェットが壁面への衝突す る衝撃的流体運動についてさらに詳細に調べその メカニズムを明らかにする必要がある.

\section{参考文献}

1) Hattori,M., A. Arami, T. Yui, Wave impact pressure on vertical walls under breaking waves of various types, Coastal Engineering, 22, pp. 79-114, 1994.

2) Klammer, P., A. Kortenhaus, H. Oumeraci, Wave Impact Loading of Vertical Face Structures for Dynamic Stability analysis -Prediction Formulae-, Int. Conf. Coastal Eng., pp. 2534-2551, 1996.

3) Azarmsa, S., T. Yasuda, H. Mitsuda, Cause and Characteristics of Impact Pressure Exerted by Spilling and Plunging Breakers on A Vertical Wall, Int. Conf. Coastal Eng., pp. 2442-2455, 1996.

4) Hattori, M., N. Tsujioka, Dynamic Responsc of Vertical Elastic Walls to Breaking Wave Impact, pp. 2456-2473, 1996.

5)渡部靖憲・佐伯浩, 砕波帯内の流速場のダイレク トシミュレーション, 海岸工学論文集, 第 43 巻, pp. $71-75,1996$

(1999. 4. 19 受付) 